\title{
Jean Cruveilhier and His Explorations
}

\author{
Rengin Kosif
}

\begin{abstract}
Jean Cruveilhier was a French anatomist and pathologist. He developed an interest in pathology, being influenced by Dupuytren, a friend of Cruveilhier's father. In 1816 he earned his medical doctorate in Paris, where in 1825 he succeeded Béclard as professor of anatomy. In 1836 he relinquished the chair of anatomy to Breschet, and in doing so, became the first occupant of the recently founded chair of pathological anatomy. In 1836 he was elected to the Académie de Médecine, becoming its president in 1839. For over forty years he was president of the Société anatomique. He died, aged 83. He was a highly influential anatomist, making important contributions in his study of the nervous system, multiple sclerosis, vascular system, phlebitis. Cruveilhier's name is associated with several parts of the anatomy and pathology however these terms have largely been replaced by the modern anatomical nomenclature. There are also many pioneer medical books of him.
\end{abstract}

Index Terms-Cruveilhier, anatomist, pathologist, his explorations.

\section{REVIEW ARTICLE}

Jean Cruveilhier (February 9, 1791 - March 7, 1874) was born in Limoges, France. Jean Cruveilhier, French anatomist, pathologist and physician who wrote several important works on pathological anatomy (Figure 1). While still a student at the College of Limoges, he decided to enter the priesthood, but was denied this career course by his energetic father, who wanted for him to become his worthy successor. Jean Cruveilhier was therefore forced to study medicine. In 1810 he moved from Limoges to Paris armed with letters to the famous Guillaume Dupuytren (1777-1835), under whom he commenced his medical studies. After his first four autopsies, however, he was so disgusted with medicine that he joined a secret order and began the study of religion at the seminary of the holy Sulpicius. As news of this reached his father, he went to Paris and got his son back to medical school, where Dupuytren, a friend of his father, made him his protégé and aroused his interest in pathology.

Continue his practice, as the minister of education, bishop Frayssinon, with whom he had become acquainted at the St. Sulpice, encouraged him to compete for the chair of descriptive anatomy, which had been vacated through the unexpected death of Pierre Béclard (1785-1825). He held his inaugural speech as professor of descriptive anatomy in Paris in 1825. In 1826 he became médecin des hôpitaux. In the same year he reorganized the Société anatomique, which had been organized in 1803 by Dupuytren and discontinued in 1808 while under the leadership of

Rengin Kosif, , Medical Faculty, Department of Anatomy, Bolu Abant Izzet Baysal University, Bolu, Turkey, 3043
René-Théophile-Hyacinthe Laënnec (1781-1826). Cruveilhier was to remain its president for over 40 years. Elected to the Académie de Médecine in 1836, he was its president in 1839. In 1836 he became the first to hold the chair of pathological anatomy, which had been established with means from his teacher, Dupuytren. At that time he had relinquished his chair of normal anatomy to Gilbert Breschet. The major shortage is in his lack of knowledge of important works published in other languages, as well as his insufficient knowledge of chemistry and histology. He died on his country estate in Sussac near Limoges, aged 83, from an inflammation of the lungs and peritoneum (1).

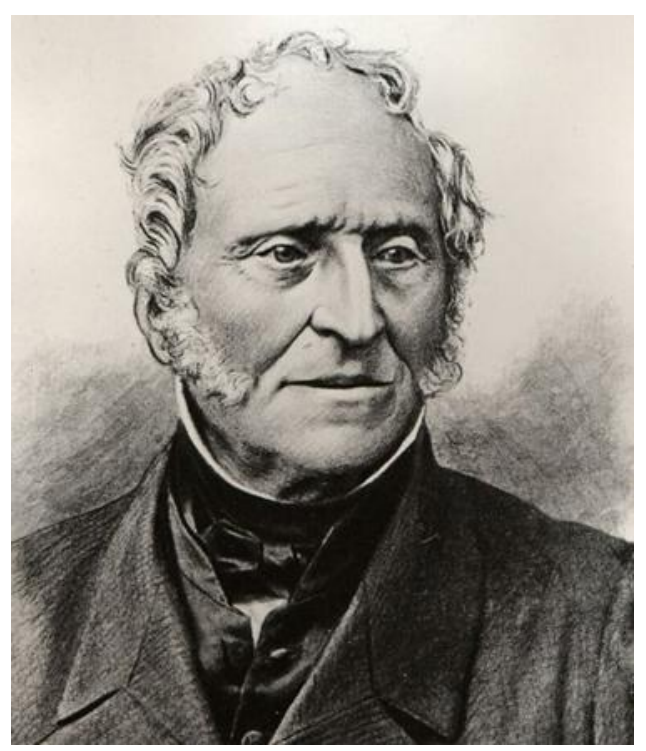

Figure 1: Jean Cruveilheir

Cruveilhier possessed a broad knowledge of morbid anatomy and published a series of multivolume works on the subject. The greatest of these, an atlas of pathology titled Anatomie pathologique du corps humain, 2 vol. (1829-42; "Pathological Anatomy of the Human Body"), had many coloured illustrations whose beauty remains unrivaled in the history of medical illustration. In the Anatomie pathologique Cruveilhier gave the first description of multiple sclerosis, depicted several cases of gastric ulcer, and left an early account of progressive muscular atrophy, which is sometimes called Cruveilhier's atrophy, or Cruveilhier's disease. His name is included in the (French) medical names for congenital cirrhosis of the liver and for stomach ulcers caused by excess acid (2).

In 1820 Cruveilhier diagnosed a cerebral tumor with localization of the lesion, which had invaded the acoustic nerve. The observation was so precise that nearly a century later (1927) Harvey Cushing found nothing to add to it. Despite his scant knowledge of histology, Cruveilhier's work 
has become less dated than some more recent ones that make the most use of the microscope (2).

Cruveilhier described a valvula at the distal extremity of the lacrimonasal canal that was also known to Giovanni Battista Bianchi and Joseph Hasner. He also gave his name to the vertebral nerve in the posterior cervical plexus that issues from the first three cervical pairs (3).

Cruveilhier's plexus: posterior cervical plexus, plexus formed by the dorsal rami of the first three spinal nerves. Cruveilhier plexus, interneural connections between the dorsal rami of theupper cervical nerves. He showed that the styloglossal and palatoglossal nerves could originate in the lingual branch of the facial nerve (Hirschfeld's nerve), which anastomoses with the glossopharyngeal (Haller's ansa) (3).

Cruveilhier-Baumgarten Disease: The disease with a patent umbilical vein, portal hypertension, and without significant changes in the liver is a rare clinical entity. Cruveilhier-Baumgarten disease is a rare condition, characterised by the presence of prominent umbilical or para-umbilical veins, abdominal venus hum with thrill, splenomegaly, normal or small liver without evidence of cirrhosis, portal hypertension with oeso-phageal varices and hypersplenism. Cruveilhier-Baumgarten sign (murmur), a murmur over the umbilicus often in the presence of caput medusae. (4).

Cruveilhier's joint: Median atlanto-axial joint. One of three points of articulation of the atlas and the axis. The median atlantoaxial joint is a pivot articulation among the dens, the axis, and the ring of the atlas and involves five ligaments. It allows rotation of the axis and the skull, the extent of rotation limited by the alar ligaments (5) (Figure 2).

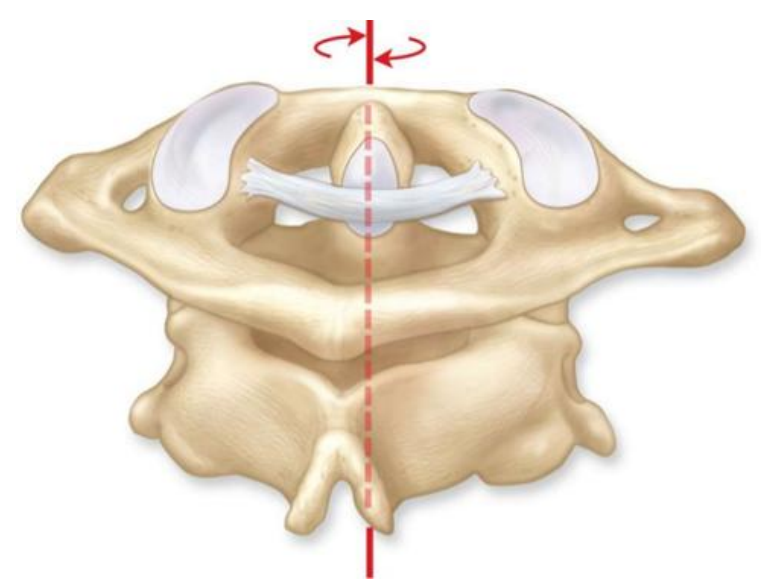

Figure 2: Median atlanto-axial joint

Cruveilhier's fossa: Scaphoid fossa of sphenoid bone.

Cruveilhier's fascia: Superficial fascia of perineum. The membranous layer of the subcutaneous tissue in the urogenital region attaching posteriorly to the border of the urogenital diaphragm, at the sides to the ischiopubic rami, and continuing anteriorly onto the abdominal wall (6).

Cruveilhier disease: Cruveilhier palsy: A disease of the motor tracts of the lateral columns and anterior horns of the spinal cord, causing progressive muscular atrophy, hyperactive deep tendon reflexes, fibrillary twitching, and spastic irritability of muscles; associated with a defect in superoxide dismutase. (Amyotrophic lateral sclerosis: ALS) (7).
Cruveilhier atrophy: A condition characterized by chronic progressive muscle wasting followed by weakness and paralysis. Affects hands, arms, shoulders and legs initially. Also called Aran-Ducheme muscular atrophy or progressive spinal muscular dystrophy (8).

Cruveilhier ligaments: Plantar ligaments. The counterparts in the foot of the palmar ligaments in the hand. Ligamenta plantaria articulationum metatarsophalangealium. Thick, dense bands on the plantar surface of the metatarsophalangeal articulations, between the collateral ligaments. Called also inferior metatarsophalangeal ligaments (9).

Cruveilhier sign: Palpable groin swelling noted when patient coughs.

Cruveilhier tumor: Brain tumors were first described macroscopically by Cruveilhier in 1829 and were classified macroscopically by Bressler in 1836 . However, the current classification of brain tumors is based on Wirchow. In 1860 he described the neuroglia as the intercellular matrix of the brain. Again by Wirchow, the connection between the macroscopic and microscopic features of the tumors has been established and the definition of 'glioma tumor' was made for the first time (10).

Cruveilhier ulcer: Ulcer of the gastric or peptic. An ulcer of the stomach (11).

He also performed extensive studies on inflammation of blood vessels, particularly phlebitis. Cruveilhier believed that phlebitis was the cause of most diseases, however this postulation was later disproved by Rudolf Virchow.

Jean Cruveilhier that current knowledge of spina bifida, hydrocephalus and Chiari II malformation is based.

Cruveilhier was a prolific writer, among his works were Anatomie pathologique du corps humain (1829-1842) and Life of Dupuytren (1840), which was a memorial to his teacher, Guillaume Dupuytren. His best-known work is Anatomie pathologique du corps humain, in which he renders a superb description of ulcer as well as the first pathological account of disseminated sclerosis. He reported a French soldier who, in 1813, was taken prisoner by Hungarian troops, beaten up and left to die, after having received an extremely heavy blow with a rifle butt. After six months in hospital he was restituted and returned to civilian life. Some years later, however, abdominal swelling troubled him and a loud murmur could be heard over his umbilicus.

His experiments on the formation of callus after bone fractures in pigeons showed Cruveilhier the importance of extraosseous tissues (periosteum, muscles) in the reconstitution of bones of leverage. His injections of mercury into the blood vessels and the bronchial system bore out the theory of phlebitis, which, he said, "dominates the whole of pathology." It made possible the conceptions of embolism and infarction, which were developed by Virchow beginning in 1846.

He died in 1874, and at autopsy his liver was found to be somewhat small in size, smaller than his spleen, but no cirrhosis was commented upon. There were large veins coursing from his umbilicus, connecting the systemic with his portal system. Cruveilhier speculated whether this could be congenital or acquired following the trauma (12).

Cruveilhier's contributions to forensic science 
predominantly involved developing precise methods of autopsy for determining the specific cause of death.The six-volume Anatomie pathologique du corps humain (1828-1842) and the Traité d'anatomie pathologique générale (1849-1864) are Cruveilhier's true claims to fame for their illustrations, remarkable even today, and for their conception (13). His medical books:

Anatomie pathologique du corps humain, ou description, avec figures lithographiées et colorieés, des diverses alterations morbides dont le corps humain est susceptible.

2 text volumes and 2 volumes atlas. Paris, J. B. Baillière, 1829-1842. This atlas contains some of the finest illustrations - more than 200 copper plates - of gross pathology ever made. They are colored lithographs, done by the anatomical illustrator, Antoine Chazal.

Essai sur l'anatomie pathologique en général et sur les transformations et productions organiques en particulier. Doctoral thesis. 2 volumes, Paris, 1816.

Médecine pratique éclairée par l'anatomie et la physiologie patholgique. Paris, 1821.

An omnis pulmonum exulceratio vel etia, excavatio insansibilis? Montpellier, 1824.

Discours sur l'histoire de l'anatomie.

Thesis for agrégé. Paris, 1825.

Cours d'études anatomiques. Paris, 1830.

Anomalie de l'artère brachiale.

Bulletins et memoires de la Société Anatomique de Paris, 1834: 40-41.

Deux cas d'anomalie dans la distribution de l'artère brachiale.

Bulletins et memoires de la Société Anatomique de Paris, 1835: 2 .

Traité d'anatomie descriptive.

4 volumes; Paris, 1834-1836.

Des devoirs et de la moralité du médecin. Discours prononcé dans la séance publique de la Faculté de Médecine, le 3 novembre 1836. Paris, 1837.

Vie de Dupuytren. Paris, 1840.

Anatomie du système nerveux. Paris, 1845.

Histoire de l'anatomie pathologique.

Annales de l'anatomie de de la physiologie pathologiques, 1846; 9-18, 37-47, 75-88.

Traité d'anatomie pathologique générale. 5 volumes; Paris, 1849-1864.

Notice sur la vie et les travaux de M. Cruveilhier, lue dans la séance publique annuelle de l'Académie de médecine, le 4 mai 1875 . Pp. 259-287 in Notices et portraits éloges lus a l'Académie de médecine par J. Béclard, Paris, G. Masson, 1878.

G. B. Bianchi: Ductus lacrymales novi; eorum anatome, usus, morbi, curationes. Torino, 1715; Leyden, 1723.

De lacteorum vasorum positionibus et fabrica. Torino, 1723.

Josef Haser (Josef Ritter von Artha): Physiologie und Pathologie des Thränenableitungs-Apparates. Prague, 1850,

(1).

\section{REFERENCES}

[1] whonamedit.com $>$ doctor.cfm/892.html.

[2] https://www.britannica.com/biography/Jean-Cruveilhier.

[3] R. Shane Tubbs, Martin M. Mortazavi, Marios Loukas, Anthony V. D'antoni, Mohammadali M. Shoja, Aaron A. Cohen-Gadol. Cruveilhier plexus: an anatomical study and a potential causeof failed treatments for occipital neuralgia and muscular andfacet denervation procedures. J Neurosurg. 2011; 115: 929-933.

[4] B Bisseru, J Spatel. Case report Cruveilhier-Baumgarten (C-B) disease. Gut. 1989; 30: 136-137.

[5] https://medical-dictionary.thefreedictionary.com/Cruveilhier+joint

[6] http://www.mondofacto.com/facts/dictionary?Cruveilhier\% $27 \mathrm{~s}+$ fascia

[7] https://medical-dictionary.thefreedictionary.com/Lou+Gehrig+disease.

[8] https://www.rightdiagnosis.com/medical/cruveilhier_s_atrophy.htm.

[9] https://medicine.academic.ru/136874/ligamenta_plantaria_articulation um_metatarsophalangealium.

[10] Bekir Tuğcu. Malign Astrositer Tümörlü Hastalarda Yaşam Süresini Etkileyen Faktörler Ve Ki-67 (Mib I) Proliferasyon İndeksinin Prognoz Üzerine Etkisi. (Uzmanlık Tezi). 2004.

[11] https://medical-dictionary.thefreedictionary.com/Cruveilhier+ulcer.

[12] https://www.bionity.com/en/encyclopedia/Jean_Cruveilhier.html

[13] https://www.encyclopedia.com/people/medicine/medicine-biographies /jean-cruveilhier.

Rengin Kosif, MD-Associate Professor

Bolu Abant Izzet Baysal University, Medical Faculty, Department of Anatomy, Bolu, Turkey 